This item was submitted to Loughborough's Research Repository by the author.

Items in Figshare are protected by copyright, with all rights reserved, unless otherwise indicated.

\title{
A seasonal forecasting procedure for reservoir inflows in Central Asia
}

PLEASE CITE THE PUBLISHED VERSION

https://doi.org/10.1002/rra.3506

PUBLISHER

Wiley

VERSION

AM (Accepted Manuscript)

\section{PUBLISHER STATEMENT}

This is the peer reviewed version of the following article: DIXON, S.G. and WILBY, R.L., 2019. A seasonal fore-casting procedure for reservoir inflows in Central Asia. River Research and Applications, 35 (8), pp.11411154, which has been published in final form at https://doi.org/10.1002/rra.3506. This article may be used for non-commercial purposes in accordance with Wiley Terms and Conditions for Use of Self-Archived Versions.

\section{LICENCE}

CC BY-NC-ND 4.0

\section{REPOSITORY RECORD}

Dixon, Samuel G, and Robert Wilby. 2019. "A Seasonal Forecasting Procedure for Reservoir Inflows in Central Asia”. figshare. https://hdl.handle.net/2134/9205577.v1. 


\section{River Research and Applications}

\section{A seasonal forecasting procedure for reservoir inflows in Central Asia}

\begin{tabular}{|c|c|}
\hline Journal: & River Research and Applications \\
\hline Manuscript ID & RRA-19-0141.R2 \\
\hline Wiley - Manuscript type: & Special Issue Paper \\
\hline $\begin{array}{r}\text { Date Submitted by the } \\
\text { Author: }\end{array}$ & $n / a$ \\
\hline Complete List of Authors: & $\begin{array}{l}\text { Dixon, Samuel; Moors for the Future Partnership } \\
\text { Wilby, Rob; Loughborough University, }\end{array}$ \\
\hline Keywords: & $\begin{array}{l}\text { Seasonal forecast, ENSO, River flow, Central Asia, Hydropower, } \\
\text { Reservoir }\end{array}$ \\
\hline
\end{tabular}

\section{SCHOLARONE Manuscripts}




\section{A seasonal forecasting procedure for reservoir inflows in Central Asia}

Samuel G. Dixon ${ }^{1}$ and Robert L. Wilby ${ }^{2 *}$

${ }^{1}$ Moors for the Future Partnership, Edale, Derbyshire, S33 7ZA, UK

${ }^{2}$ Department of Geography and Environment, Loughborough University, Leicestershire, LE11 3TU, UK

${ }^{*}$ Corresponding author: r.l.wilby@lboro.ac.uk

Main text, references, figure captions and tables word count: 7616

Version R2 submitted to:

River Research and Applications - Special Issue 


\begin{abstract}
This study develops a procedure for seasonal forecasting river discharge from headwaters above strategically important hydropower plants in Kyrgyzstan and Tajikistan. The EI Niño Southern Oscillation, North Atlantic Oscillation and Indian Ocean Dipole indices were used as inputs. Predictability was evaluated for average summer inflows conditional on the tercile of the preceding winter climate mode. We find that the winter Niño 3.4 index was significantly positively correlated with following summer inflows to Nurek, Andijan and Toktogul reservoirs during the period 1941-1980. Kruskal-Wallis and Kolmogorov-Smirnov tests show significant differences in the distributions of summer inflows depending on previous winter Niño 3.4 for all three reservoirs. At Nurek, summer inflows were on average $19 \%$ greater following a winter El Niño. During 1941-2016, mean summer inflows to Nurek reservoir linked to previous November-December Niño 3.4 achieved a Heidke Hit Proportion of $51-59 \%$ (compared with $33 \%$ expected by chance). Acceptable predictions of summer inflow volume were made $44 \%$ of the time. Higher inflows are explained by a south westerly moisture flux that brings above average precipitation to Central Asia during winter EI Niño conditions. Our procedure requires limited data, technical or computing resources - all considerations in data sparse, low capacity regions. Given planned developments of other large, headwater impoundments in Central Asia, early outlooks of discharge could contribute to improved dam safety, economic performance and transboundary water sharing around such projects.
\end{abstract}

\title{
Key words
}

Seasonal forecast, ENSO, river flow, Central Asia, hydropower, reservoir 


\section{Introduction}

Water systems in Central Asia (CA) are amongst the most complex in the world (Raskin et al., 1992). The region has two major rivers - the Amu Darya and Syr Darya - which are regulated by more than 60 large impoundments (Rakhmatullaev et al., 2010). These rivers and reservoirs ultimately drain into the Aral Sea having passed through six countries (Afghanistan, Kazakhstan, Kyrgyzstan, Tajikistan, Turkmenistan, Uzbekistan). Given the extent of transboundary water resources, there has understandably been differing views about reservoir operations and further dam construction (World Bank, 2004; European Commission, 2008; Reuters, 2012). In general, upstream nations want to maximise hydropower generation during winter whereas downstream countries prioritise water for irrigation in summer. However, dam safety, high rates of sedimentation in reservoirs, and the need to rehabilitate ageing infrastructure are shared concerns.

Large impoundments can play an important role in regional development (Rakhmatullaev et al., 2010) but well-coordinated asset management and reservoir operations presupposes integrated monitoring and forecasting systems (Clausen et al., 2014). Open access, remotely sensed data can support these aspirations by improving resource estimation and forecasting (Dixon and Wilby, 2016). For instance, long lead river discharge forecasts facilitate increased hydropower production and reduced spillage, with potential annual economic benefits of $\$ 153$ million demonstrated for the Columbia River, North America (Hamlet et al., 2002; Maurer and Lettenmaier, 2003). Until recently, there have been surprisingly few applications of such techniques to CA (e.g. Apel et al., 2018; Gerlitz et al., 2016).

Nonetheless, climate modes such as the El Niño Southern Oscillation (ENSO) are known to influence regional precipitation, droughts and floods (Redmond and Koch, 1991; Chiew et al., 1998; Cayan et al. 1999; Dai and Wigley, 2000; Chiew and McMahon, 2002; Wang et al., 2014; Emerton et al., 2017). Such relationships, when stationary and of practical significance, can be leveraged for seasonal forecasting (Hamlet and Lettenmaier, 1999). Climate mode-streamflow relationships are currently used within operational hydrologic forecasting systems such as BC Hydro (Sene, 2016) and the US Department for Agricultures Natural Resources 
Conservation Service ${ }^{1}$. Forecasts are made via linear and non-linear relationships between climate modes and seasonal streamflow (Barlow and Tippet, 2008; Kennedy et al., 2009; Fleming and Dahlke, 2014) and mode-based weighting schemes for ensemble streamflow prediction (Werner et al., 2004). Statistical forecasting techniques based on remote climate modes offer significant potential for regions with sparse ground-based monitoring networks, like in CA.

As far as we are aware, little attention has been paid to possible links between climate modes and regional discharge in $\mathrm{CA}$. This may reflect the complex regional hydro-meteorology and relative remoteness from modes of climate variability (Mariotti, 2007). However, Syed et al. (2006) have reported weak negative correlations between the North Atlantic Oscillation (NAO) and winter precipitation across Tajikistan and Kyrgyzstan; and Barlow and Hoell (2015) identified a link between NAO and drought in south west CA. Negative correlations have also been found between NAO and mean December-March precipitation and streamflow across the Middle East (Cullen and Demenocal, 2000; Cullen et al., 2002).

Conversely, precipitation (Dai and Wigley, 2000; Syed et al., 2006; Mariotti, 2007; Syed et al., 2010; Dimri, 2013; Lee et al., 2018), discharge anomalies (Barlow and Tippet, 2008; Emerton et al., 2017) and hydropower production ( $\mathrm{Ng}$ et al., 2017) are typically positive during El Niño episodes, whereas, drought in south west CA is more likely under concurrent La Niña (Barlow et al., 2002; Hoerling and Kumar, 2003; Barlow and Hoell, 2015). Likewise, CA experiences below average precipitation and higher temperatures under strong Asian monsoons (Schiemann et al., 2007). Tippett et al. (2005) report significant cross validated skill of SST driven General Circulation Model predictions compared with observed precipitation across Tajikistan and western Kyrgyzstan. Summer (April-August) discharge has been forecast from winter tropical Pacific SSTs and winter precipitation with significant cross-validated correlations $(r>0.5)$ (Barlow and Tippet, 2008). Hence, there is a basis for using winter climate modes and Pacific SST anomalies to forecast subsequent summer discharge across parts of CA.

\footnotetext{
1 https://www.wcc.nrcs.usda.gov/wsf/
} 
This paper has two aims. First, we evaluate spatial and temporal variations in correlations between selected climate modes versus precipitation, temperature and reservoir inflows for three large hydropower plants in CA. Second, we develop a straightforward procedure for creating early outlooks of summer inflows at one of these sites (Nurek reservoir, Tajikistan) using previous winter Niño 3.4. Earlier research has linked climate modes to winter CA precipitation (Tippett et al., 2005; Gerlitz et al., 2016) and summer flow (Barlow and Tippett, 2008). This study adds to knowledge in two ways. First, by reconstructing then analysing a multi-decadal summer inflow series to critical infrastructure. Second, by demonstrating the decision support potential of compositing such data by climate mode. Our study area, observed, and reconstructed data series are described next. Section 3 then presents the statistical analyses and procedure development. Section 4 evaluates the potential predictability of inflows to three test reservoirs. Section 5 discusses these results with respect to previous literature and speculates about the physical processes involved. Finally, section 6 summarises the key findings and considers the scope for wider applicability of seasonal climate outlooks in CA.

\section{Study area and data}

\subsection{Study area}

Most precipitation in CA originates from westerly air masses, with totals declining along a west to east gradient. The Hindu-Kush, Pamirs and Karakoram mountains impede intrusion by air masses from the south (Schiemann et al., 2007). The annual precipitation regime is more pronounced over the mountainous areas than the lowlands: in the Pamirs the maximum is typically in early spring; across the Tien Shan there are maxima in late spring and in autumn (Schiemann et al., 2008).

Toktogul (Kyrgyzstan), Andijan (Kyrgyzstan) and Nurek (Tajikistan) reservoirs are used to develop our seasonal forecasting procedure. These impoundments have a key role in regulating the headwaters of the Syr Darya and Amu Darya (Figure 1a). The inflow regimes of Toktogul and Andijan are classified as snow-ice, whereas Nurek is ice-snow driven (Schiemann et al., 2007). The former has relatively high flows in spring compared with summer due to melting snowpack; the latter has higher flows in summer than spring because of the predominance of glacier- over snow-melt. This is reflected by the timing of their maximum inflows (Table 1), which 
are typically earlier for Toktogul and Andijan than for Nurek. All three reservoirs are used for hydropower, irrigation and flood control.

\subsection{Observed hydro-meteorological data}

High-quality, long homogeneous hydrological records are very rare in CA.

Nonetheless, observed monthly reservoir inflows were obtained from the Global Runoff Data Centre ${ }^{2}$ for 1941-1980 and from CAWater-info ${ }^{3}$ for 2001-2010.

Discharge data for Nurek reservoir inflows were also obtained from Tajikistan Hydromet for the period 1981-2016 (1993-1999 missing). Periods with available discharge data are summarised in Figure 1b. Monthly observed precipitation and temperature were acquired for Naryn, Uzgen and Sari-Tash from the Central Asia Database $^{4}$. Monthly precipitation and temperature were also obtained for Garm meteorological station from Tajik Hydromet. Monthly NCEP re-analysis precipitation and temperature for the domain bounded by $35^{\circ}-48^{\circ} \mathrm{N}$ and $55^{\circ}-82^{\circ} \mathrm{E}$ were analysed for teleconnections (section 2.4) via the NOAA Earth Science Research Laboratory (ESRL) Pearson correlation tool ${ }^{5}$ using data for the period 1950-2014.

\subsection{Reconstructing summer inflows for Nurek}

Discharge data for Nurek were obtained from gauging stations at Komsomolabad and Garm (upstream). A 'blended' series was then created for 1941-2016 by regressing mean summer (April-September) flows at Garm against Komsomolabad using overlapping periods of data (1949-1957, 1977-86, 1988 and 1990) (Figure 1b). This regression model explained $60 \%$ of the variance in mean summer flow at Komsomolabad. Mean summer flows are insignificantly autocorrelated $(r=0.34$, $p>0.1$ ); there is also no significant trend in the series over the period used. The final blended flow series for Komsomolabad uses observed values where possible, filling any gaps in the series with predicted values from the regression model (Figure 1c). No data are available for either gauge during the period 1993-1999.

\footnotetext{
2 http://www.bafg.de/GRDC/EN/Home/homepage_node.html

${ }^{3} \mathrm{http} / / / \mathrm{www}$.cawater-info.net/bd/index_e.htm

${ }^{4} \mathrm{http}: / / \mathrm{www}$.webpages.uidaho.edu/cae/data/index.html

$5 \mathrm{https} / / / \mathrm{www}$. esrl.noaa.gov/psd/data/correlation/
} 


\subsection{Climate indices}

The NAO, ENSO and Indian Ocean Dipole (IOD) were evaluated with respect to the regional hydro-climatology. These indices were chosen based on previous studies (e.g. Mariotti, 2007; Barlow and Hoell, 2015) as well as our analysis of global SSTs in relation to inflow series. The Hurrell Principal Component based NAO ${ }^{6}$ index was used in preference to station-based NAO indices because the former better characterizes hemispheric circulation patterns (Hurrell and NCAR Staff, 2016). Hadley Centre Sea Ice and Sea Surface Temperature (HadISST) data ${ }^{7}$ provide a long record of Niño 3.4, the preferred ENSO index of forecasters (Barnston et al., 1997). The Dipole Mode Index (DMI) describes the IOD, and the SST-based DMI index used originates from the Japan Agency for Marine-Earth Science and TEChnology ${ }^{8}$.

\section{Methods}

\subsection{Correlation analysis}

Preliminary explorations were undertaken to identify ocean basins with strongest concurrent and lagged correlations with seasonal inflows to the three study reservoirs. The ESRL tool ${ }^{5}$ was used to correlate NAO, Niño 3.4 and DMI indices with NCEP re-analysis precipitation and temperature across CA for each month during the period 1950-2014, with the index leading over 0 to 3 months. Although the NCEP re-analysis can struggle to represent local scale precipitation variations, the product does capture the spatial distribution of observed precipitation at large scales (Schiemann et al., 2008). The non-parametric Spearman Rank correlation was used to test associations between summer inflows and prior winter NAO, Niño 3.4 or DMI over the periods 1941-1980 and 2001-2010. Summer flows were selected as these contribute between $77 \%$ to $83 \%$ of mean annual inflow (Table 1 ).

\subsection{Composite analysis}

The period 1941-1980 was examined first to minimize possible non-stationarity due to discharge data non-homogeneity and/or anthropogenic climate change in the region. Average summer inflows were pooled conditional on the tercile (i.e. $<33 \%$,

\footnotetext{
${ }^{6} \mathrm{https}: / /$ climatedataguide.ucar.edu/climate-data/hurrell-north-atlantic-oscillation-nao-index-pc-based

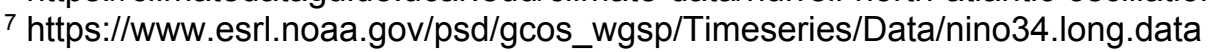

${ }^{8} \mathrm{http}: / / \mathrm{www} . j a m s t e c . g o . j p / \mathrm{e} /$
} 
$33-66 \%,>66 \%$ ) of prior winter SSTs. This enables evaluation of equal size samples (in this case 13 or 14 years in each sub-set) of summer flow conditional on prior SST index (negative, neutral or positive). Significance of differences between pooled samples was assessed using the: (1) Kolmogorov-Smirnov (KS) test of maximum difference between two cumulative distributions; (2) Kruskal-Wallis (KW) test of differences in ranked values of multiple distributions. Cumulative distributions and tables of anomalies show expected inflows following negative, neutral or positive indices. Summer air temperature terciles (as a proxy for snowmelt contributions) were also assessed for their ability to condition summer inflows.

The blended inflow record for Nurek was also stratified using the compositing technique described above. Forecast skill was assessed via the Heidke Hit Proportion (HHP), defined as the fraction of cases in which the forecast category assigned the highest likelihood is later observed (International Research Institute, 2013). In our three-state model a score of 0.33 would be expected by chance; hence higher values indicate statistical skill. The entire time series was split, allowing crossvalidated HHP scores to be calculated for 1941-1974 and 1975-2016. Finally, for comparability with the multiple linear regression model of Apel et al. (2018), we calculated the proportion of forecasts that would be regarded as 'acceptable' during the common period 2000-2015. This is a forecast with absolute residuals (between observed and expected inflows) that are less than $68 \%$ of the standard deviation of the observed seasonal discharge.

\section{Results}

\subsection{Correlation analysis}

The NAO was weakly correlated with concurrent NCEP re-analysis precipitation across CA throughout the year and over lead times of 1 to 3 months (not shown). Only April precipitation across southern Tajikistan showed significant $(p<0.05)$ negative correlations with NAO over lead times of 1-2 months. Niño 3.4 was most positively correlated with CA precipitation in winter (Figure 2a). Both January and March showed significant $(p<0.05)$ concurrent and lagged positive correlations $(r>0.25)$ south-east of the Aral Sea. Significant positive correlations $(r>0.25)$ were also present across western Tajikistan and Uzbekistan during October, with stronger 
correlations ( $r \sim 0.35)$ over Iran and north-western Afghanistan. DMI was insignificantly correlated with CA precipitation (not shown).

Negative correlations $(r \sim 0.4, p<0.05)$ existed between NAO and air temperature across southern CA during January (concurrent only), February (lead 0-1 month) and March (0-2 months) (not shown). These correlations were strongest across Tajikistan and northern Afghanistan, but also apply to parts of Kyrgyzstan. November and December temperatures were negatively correlated $(r \sim 0.30, p<0.05)$ with NAO over north-eastern Iran. Niño 3.4 showed positive correlation $(r \sim 0.3, p<0.05)$ with January and February temperature over eastern Kyrgyzstan and north-west China at lead 1-3 months, but insignificant positive correlations across Tajikistan at all leads (Figure $2 b)$. Stronger, negative correlations $(r \sim-0.4, p<0.01)$ were present over northern Kyrgyzstan and Kazakhstan during May over leads 1-3 months.

January and January-February mean NAO were negatively correlated $(r \sim-0.40$, $p<0.05$ ) with summer inflows to all reservoirs during 1941-1980 (Table 2). December NAO was negatively correlated $(r \sim-0.70, p<0.05)$ with summer inflows to Toktogul and Andijan during 2001-2010. Winter Niño 3.4 was significantly correlated with following summer inflows for Toktogul, Andijan $(p<0.05)$ and Nurek $(p<0.01)$ reservoirs during 1941-1980. Fewer significant correlations were seen during the years 2001-2010, yet correlations remain relatively strong for all months at all reservoirs $(r \sim 0.55)$. DMI (March) showed significant correlation to following summer inflows only for Nurek (Table 2).

\subsection{Composite analysis}

During 1941-1980, the largest difference in summer inflows occurred after opposing Niño 3.4 phases (Figure 3). Nurek shows most potential for conditioning by prior indices, with increased (decreased) inflows expected after winter EI Niño (La Niña) $(+19 \% /-12 \%)$ and during warm (cold) summers (+6\%/-5\%) respectively. KS tests show significant $(p<0.01)$ differences between distributions of inflows to all reservoirs following El Niño or La Niña winters, as well as for inflows to Nurek during cold / warm summers (KS $=0.57, p<0.01$ ). The greatest differences were between summer inflows to Nurek following winter La Niña / EI Niño $(K S=0.85, p<0.01)$ or between winter neutral / EI Niño conditions (KS $=0.85, p<0.01)$. KW tests further support the 
view that there were significant $(p<0.01)$ differences in summer inflows to all reservoirs depending on winter Niño 3.4 (Toktogul KW = 9.9, Andijan KW = 10.2), Nurek KW = 20.9). In contrast, none of the differences in exceedance probability distributions conditioned by NAO, DMI or temperatures were significant.

\subsection{Predictability of Nurek reservoir inflows}

The predictability of Nurek inflows was examined using the blended discharge record for Komsomolabad (section 2.3). Nurek summer inflows were again conditioned on prior winter Niño 3.4 phase for the periods 19412016 and 1981-2016 (years 1993-1999 missing) to evaluate long-term and more recent associations compared with 1941-1980. The KS and KW tests show significant differences $(p<0.01)$ in Nurek inflows following El Niño/La Niña when using the full inflow series (i.e. 1941-2016). Although the period 1981-2016 has on average 4\% more inflow following El Niño (and 7\% less following La Niña) (Figure 4a), these differences are not statistically significant. Even so, a variation of summer inflow by $11 \%$ equates to an estimated loss of $\sim \$ 8$ million in hydropower revenue at this one site ${ }^{9}$. Hence, even a weaker winter Niño 3.4 signature still has economic significance.

\subsection{Scope for operational outlooks}

Exceedance probabilities for reservoir inflows that are conditional on October-March Niño 3.4 could be issued in April, as soon as the March Niño 3.4 index is published. However, operators of Nurek would like to have an earlier outlook of summer inflows. Therefore, November-December mean Niño 3.4 was used to condition following summer (April-September) inflows to Nurek, bringing the month of outlook issue forward to January. Differences in summer inflows following contrasting NovemberDecember phases of Niño 3.4 were greater during 1941-1980 (KS $=0.85, p<0.01$ ) than over the full record $1941-2016$ (KS $=0.59, p<0.01)$. On the other hand, inflow exceedance probabilities are the same when conditioning by November-December mean Niño 3.4 in 1941-1980 as in 1941-2016 (KW = 20.9, $p<0.01)$. January and April outlooks have the same skill (according to the HHP) when tested against 1975-

\footnotetext{
9 One cumec of flow over a summer equates to $\$ 77,760$ revenue from electricity generation for domestic use in Tajikistan (assuming $\$ 0.02$ per kWh electricity at 2017 prices)
} 
2016, but the January outlook is better when cross-validated against 1941-1974 (0.59 compared to 0.53 respectively) (Table 3 ).

Likelihoods of high, normal or low inflows could be presented to decision-makers in the form of contingency tables. For example, based on reconstructed flows for the period 1941-2016 (Table 4a), there is a $63.6 \%$ chance of higher than average summer inflows to Nurek following El Niño, compared with $14.3 \%$ after La Niña. Conversely, the likelihood of below average inflows is $4.5 \%$ following El Niño, but $52.4 \%$ after La Niña. Tables $4 \mathrm{~b}$ and $4 \mathrm{c}$ show the extent to which these likelihoods have changed between the first and second half of the available record. Overall, there has been a reduction in the likelihood of above average inflows following El Niño from $77.8 \%$ in $1941-1974$, to $61.5 \%$ in $1975-2016$. Similarly, the association between La Niña and below average flows has weakened over the same period. This weakening of the association between November-December mean Nino3.4 and summer inflows to Nurek is evident in the changing regression relationship between the two variables (Figure 4b). Nonetheless, a leave one out cross-validation approach was applied to the 2000-2015 regression fitting to enable comparison with Apel et al. (2018). In both cases, an 'acceptable' forecast is returned for $44 \%$ of summers. The number of skilful forecasts for $1941-1992$ based on Nino3.4 is $54 \%$.

\section{Discussion}

\subsection{Correlation analysis}

Previous studies show weak concurrent negative correlations between NAO and precipitation over parts of CA (Aizen et al., 2001, Syed et al., 2006). Our results generally agree with this research but reveal only insignificant negative correlations between NAO and precipitation in the same areas.

Our positive correlation between Niño 3.4 and CA precipitation confirms earlier work. The association is strongest during the winter half-year $(p<0.05)$, consistent with Dai and Wigley (2001) who report positive anomalies of up to $50 \mathrm{~mm}$ over CA during El Niño phases. Syed et al. (2006) and Mariotti (2007) showed that the strongest correlations occur during autumn and spring. October, November, December and March have areas with statistically significant positive correlations across parts of Central and Western Tajikistan (Figure 2a). However, the statistically significant 
positive correlations found by Mariotti (2007) for south-east Kyrgyzstan did not emerge from our analysis. Only an insignificant positive correlation was detected over north-east Kyrgyzstan during winter months.

Our significant $(p<0.05)$ negative correlations between NAO and January and February temperature across Tajikistan are stronger than those reported by Syed et al. (2006) and Hurrell and van Loon (1997). However, Syed et al. (2006) used composites of temperature rather than correlation analysis. Furthermore, the fourmonth period used by both studies could be masking the significant associations found here during January and February. ENSO is typically linked to positive winter temperature anomalies in CA (Hurrell and van Loon, 1997; Syed et al. 2010), a finding corroborated by the significant positive correlations found during JanuaryFebruary across Kyrgyzstan (Figure 2b). No previous studies have reported the strong, significant negative correlation during May across Northern Kyrgyzstan and Kazakhstan. In the Tien Shan, May is often the wettest month. Hence, temperature anomalies during this period could be important in determining whether precipitation falls in liquid or frozen state at higher elevations.

The significant negative correlations between January-February NAO and following summer inflows to all three reservoirs is consistent with the modest negative correlations between NAO and precipitation during January-March across some parts of CA (Table 2). This result suggests that there could be a negative association between NAO and winter rainfall/snow accumulation, leading to an indirect association between winter NAO and summer inflows.

Winter Niño 3.4 is positively correlated with both concurrent winter precipitation across Tajikistan (Figure 2a) and following summer inflows to Nurek reservoir (Table 2). This suggests that Niño 3.4 has power to discriminate winter precipitation accumulations and thence summer inflows. Weaker, but still significant correlations between winter Niño 3.4 and following summer inflows to Andijan and Toktogul again fit with the positive, though insignificant, correlations with precipitation over north eastern Kyrgyzstan during several winter months (Figure 2a). 
Overall, the significant correlations between winter Niño 3.4 and reservoir inflows suggests feasibility of producing outlooks for Nurek summer inflows conditional on winter Niño 3.4 (Table 2). Moreover, by using Niño 3.4 in November-December, it would be possible to issue an early outlook of summer inflows - well before the end of the snowpack accumulation period (October-March). Existing operational methods within Tajikistan and more generally across CA require input data on snowpack depth or area by the end of spring (e.g. Barlow and Tippett, 2008), thereby limiting the range of the forecast. Even so, our results must be interpreted with caution because of the large number of statistical tests performed and likelihood of Type I errors (i.e. false correlations). Given an error rate $p=0.05$, about four significant results could have occurred by chance when correlating Niño 3.4 to following summer inflows. However, with 44 significant associations between Niño 3.4 and summer inflows detected (Table 2), the association is considered robust.

\subsection{Composite analysis}

The composite analysis supports the findings of the correlation tests, with Niño 3.4 emerging as the most promising variable for predicting inflow anomalies, especially for Nurek (Figure 3). Differences of up to $\pm 11 \%$ occur in summer inflows follow contrasting NAO phases, but these were not statistically significant for any reservoir. Inflows after positive NAO show greater differences between neutral conditions compared with negative conditions. Below average summer flows after positive NAO phases is consistent with Aizen et al. (2001) and our correlation analysis. Negative correlations between NAO and winter precipitation (Aizen et al., 2001; Syed et al., 2006) translate into less snowpack and hence lower summer inflows, as shown in Table 2 and Figure 3.

Typically, El Niño conditions during winter are followed by higher summer inflows to all three reservoirs. The summer inflow anomaly for Nurek reservoir after a winter El Niño can be as high as $+37 \%$. Figure 3 hints at a southwest to northeast gradient in the influence of Niño 3.4 on discharge. Mariotti (2007) suggests that the link between Pacific SSTs and CA rainfall anomalies is not direct, but via intervening atmospheric circulations over the Arabian Sea and Middle East (see section 5.3). 
The influence of summer air temperature on summer inflows varies by reservoir. It might be expected that higher temperatures would drive increased meltwater and, therefore, greater inflows, as seen for Nurek. However, very little difference in temperature-conditioned inflows is seen at Andijan and above average temperatures are associated with below average inflows to Toktogul (Figure 3). Similar results reported by Archer and Fowler (2008) for the Indus basin were attributed to higher evaporative losses (Singh and Bengtsson, 2005). If all winter snow accumulation melts each year regardless of the temperature anomaly, total summer runoff volume will be moisture (precipitation minus evaporation) rather than energy (temperature) limited. This is plausible for Toktogul and Andijan as they have a greater proportion of flow from snowmelt than Nurek (Table 1) (Savoskul and Smakhtin, 2013). Other studies show that winter precipitation totals are a useful predictor of summer flow, particularly for the Syr Darya, giving further weight to this hypothesis (Schär et al., 2004; Dixon and Wilby, 2016).

\subsection{Physical basis of the ENSO signal}

Confidence in seasonal forecasting is strengthened when plausible physical explanations are offered (McGregor, 2017). Syed et al. (2006) suggested a direct influence of the warm ENSO phase on CA precipitation. However, later research proposed that the atmospheric moisture flux enters CA via the southwest, circulating clockwise around a large high-pressure anomaly (Figure 5a) (Mariotti, 2007). In this conceptual model, moisture is advected across the Middle East mainly from the Arabian Sea. During December-January-February the moisture flux moves southwards, resulting in westerly transport of moisture around $20^{\circ} \mathrm{N}$ and is only connected to CA via a secondary southerly flux (Mariotti, 2007).

This mechanism has since been corroborated by other studies for both CA and nearby regions (Barlow and Tippet, 2008; Yadav et al., 2010; Cannon et al., 2015). Further evidence for a south-westerly moisture flux into CA during El Niño is provided by Figure $5 b$ and $5 c$ which show positive correlations between Niño 3.4 and GPCP precipitation across the Middle East south west of CA. The Pamirs hinder moisture from reaching the Tien Shan, thereby weakening the connection between El Niño and precipitation in northeast CA. This mechanism neatly explains the spatial 
and temporal variation in correlations presented here between Niño 3.4, precipitation and discharge.

The reconstructed discharge series for Komsomolabad was used to evaluate variations in the strength of the Niño 3.4-Nurek inflow relationship throughout 19412016. Inflows to Nurek during 1981-2016 were on average higher (lower) following winter El Niño (La Niña) conditions (Figure 4a). Although these differences are not statistically significant, they may still be economically significant. Furthermore, our analysis is hampered by the small sample size due to missing data for 1993-1999 (including the very strong El Niño of 1997/98 which CA-Water Info report as the highest summer inflow to Nurek since 1991). Rising air temperatures in recent decades may have also favoured proportionately greater contributions of glacier melt to total summer inflows, thereby weakening the association between winter Niño 3.4 and the precipitation-snowmelt fraction.

Lower discriminatory power of Niño 3.4 during later decades (Table 4a, 4b and 4c) could also be explained by a weakening ENSO-Indian Monsoon relationship over the same period (Kumar et al., 1999; Krishnaswamy et al., 2015). This waning has been attributed to a warmer climate and strengthening of the IOD-Indian Monsoon relationship (Kumar et al., 1999; Ashok et al., 2001). It is plausible that the link between ENSO and CA is, like ENSO and the Indian Monsoon, becoming weaker and/or that it is being modulated in concert with other climate modes such as the IOD and/or NAO. However, the significant $(p<0.01)$ differences over the full record (1941-2016) alongside the postulated physical mechanism (above) give confidence that ENSO phases do condition Nurek inflows. This view is supported by other analyses of hydrological extremes in the region (e.g. Wang et al., 2014; Emerton et al., 2017).

\subsection{Operational implementation of outlooks and wider applications}

The authors believe that the limited data needs and straightforward procedure developed here is well suited for use in the region (Figure 6). The method should not be used independently, but in concert with forecasts issued by Tajik Hydromet each April. However, our procedure adds value in two ways. First, the issue date of the outlook can be extended from April to January. Second, the ENSO state is a proxy 
integrator of rainfall (snowpack) and temperature anomalies. Given the decline in the number of manual and helicopter-based snow surveys in recent years, this information helps to provide an early outlook of meltwater volumes expected in the following spring and summer. Both our procedure and Apel et al. (2018) yield 'acceptable' January forecasts of summer flows in the Amu Darya 44\% of the time during 2000-2015, even though snow data are not used in our procedure.

Using November-December Niño 3.4 to forecast following summer inflows enables an early outlook to be produced in January, before a second forecast is issued in April based on October-March Niño 3.4. November-December Niño 3.4 shows greater discriminative power during the first half of the record than in the second (Table $4 b$ and $4 c$ ). This pattern is replicated by the relative skill of each model for different validation periods, with November-December Niño 3.4 showing greater skill than October-March using the validation period 1941-1974 but equal skill when using 1975-2016 (Table 3). It might be expected that the later information available from October-March Niño 3.4 would improve skill relative to November-December Niño 3.4. However, the HHP skill scores do not match this expectation. This could be explained by the strong signal during November-December being diluted across October-March, thereby reducing forecast skill.

Despite the benefits of simplicity and pragmatism, the approach advocated is not without limitations. First, a judgement must be made about what constitutes practical as opposed to statistical skill. An HHP of 51-59\% exceeds chance (33\%) but whether this level of skill is useful partly depends on the appetite for risk of failure by the decision-maker. Second, flexible operating rules are a prerequisite of improved reservoir management linked to seasonal forecasts. According to reservoir operators in Tajikistan, this might not be an immediate option.

Forecast value is also partly determined by the amount of active storage in a reservoir. In the case of Nurek, this is just $4 \mathrm{~km}^{3}$ of $10.5 \mathrm{~km}^{3}$ total storage capacity. This active storage is fully depleted every winter then replenished during summer, with the reservoir spilling most summers. Here, the value of an earlier outlook of summer inflow anomalies is in planning releases and improving the safety of reservoir spill. However, with the Central Asia South Asia Electricity Transmission 
and Trade Project (CASA-1000) expected, potentially 1300 megawatts could be exported to Pakistan during summer. This would draw down summer reservoir stores, so outlooks of expected inflows could be used to schedule operations. Additionally, power production from the Rogun hydropower project began in November 2018. Seasonal forecasts could help plan the filling and operation of new reservoirs during commissioning. For example, if a winter prior to planned filling is $\mathrm{La}$ Niña, the schedule could be extended to protect downstream summer irrigators.

The approach could be extended, with modification, beyond reservoir inflows to other precipitation and temperature driven hazards (e.g. avalanches and mudflows). Alternatively, region-wide outlooks could facilitate improved transboundary water management (based on agreed strategies linked to specified modes of climate variability). Possibly the greatest opportunity for development is in producing outlooks of winter heating degree days. Significant $(p<0.05)$ correlations exist between Niño 3.4 and January/February temperatures across Tajikistan and Kyrgyzstan (Figure 2b). An outlook of higher demand could trigger scheduling of increased imports of electricity (through CASA-1000) or stockpiling of emergency humanitarian relief before a harsh winter.

\section{Conclusions}

We have explored the feasibility of creating outlooks of summer inflows to three strategically important impoundments in CA with lead times up to 3 months, based on widely available indices of climate modes. On-going development of large, headwater hydropower plants in CA (e.g. Rogun and Kambarata) is a source of tension (Reuters, 2012). Long range seasonal river flow forecasts could be part of a package of measures to strengthen the coordination of shared resources and operation of assets that lie in cascading systems (Clausen et al., 2014). Where there is enough active storage, example interventions might include larger releases for hydropower generation during a winter with EI Niño conditions, confident in the expectation that stocks will likely be replenished in subsequent summer months.

Using November-December Niño 3.4 allows an outlook to be issued in January, well ahead of the start of the snowmelt season. HHP scores show that NovemberDecember Niño 3.4 has skill at forecasting the tercile of mean summer inflow to 
Nurek. However, deeper evaluation of the stationarity and robustness of these relationships is hampered by the small sample sizes. Similar analysis for flood prone headwater basins, such as the Panj might be feasible. Up to date hydrometeorological records are very difficult to obtain for the region but, where such data are held by national hydromet agencies or can be estimated from satellite products, it is clearly in their interest to evaluate predictability. Missing inflow data for the period 1993-1999 could be reconstructed via water balance modelling.

No two El Niño events are ever the same, due to variations in peak amplitude, duration, timing and spatial patterns of SST anomalies (Mason and Goddard, 2001). Further research is needed to determine whether outlook skill can be improved by incorporating such factors. Additionally, the relationship between ENSO and CA discharge is likely modulated by SSTs in other oceans or by interactions with the NAO. Our composite analysis provides insight to the uncertainty in seasonal discharge forecasts. However, the 69 years of data will not capture the full extent of the relationship between ENSO and CA discharge. Hence, conditions outside of those presented here should be expected in the future.

Despite these limitations, we have shown significant differences in observed inflows to Nurek reservoir conditioned on previous November-December and October-March Niño 3.4 phase, using readily available climate mode indices along with a straightforward compositing method. Such techniques are low cost, require relatively little skill or computing resources, and can be applied to remotely sensed products all considerations in data sparse, low capacity regions. With the current construction of further large, headwater impoundments in CA, strengthened regional seasonal flow-forecasting capabilities could improve the safety, operation and international cooperation around such projects. Furthermore, our procedure could be extended to other variables of interest, such as winter energy demand, risk of spring geohazards, or to summer electricity trading. Outlooks could even inform the timing of filling of new reservoirs or to help hedge water-energy resources across the region.

\section{Acknowledgements}

We dedicate this paper to the memory of Geoff Petts who was respectively the PhD 'grandfather' and 'father' to the authors. We trust that his passion for multi- 
disciplinary and practical applications of hydrological science shines through our work. We thank the CAWater-info database, the Global Runoff Data Centre and Tajik Hydromet for providing discharge data. We are also grateful to Richenda Connell for her guidance and encouragement. RLW's work in Tajikistan was supported by the European Bank for Reconstruction and Development.

\section{Data Availability Statement}

Data sharing is not applicable to this article as data analysed were provided by third parties on the understanding that they are not distributed. Where the data are in the public domain, links have been provided to the primary source.

\section{References}

Aizen, E.M., Aizen, V.B., Melack, J.M., Nakamura, T. and Ohta, T. (2001).

Precipitation and atmospheric circulation patterns at mid-latitudes of Asia. International Journal of Climatology, 21, 535-556.

Apel, H., Abdykerimova, Z., Agalhanova, M., Baimaganbetov, A., Gavrilenko, N., Gerlitz, L., Kalashnikova, O., Unger-Shayesteh, K., Vorogushyn, S. and Gafurov, A. (2018). Statistical forecast of seasonal discharge in Central Asia using observational records: development of a generic linear modelling tool for operational water resource management. Hydrology and Earth System Sciences, 22, 2225-2254.

Ashok, K., Guan, Z. and Yamagata, T. (2001). Impact of the Indian Ocean dipole on the relationship between the Indian monsoon rainfall and ENSO. Geophysical Research Letters, 28, 4499-4502.

Barlow, M. and Hoell, A. (2015). Drought in the Middle East and central-southwest Asia during winter 2013/14. Bulletin of the American Meteorological Society, 96, 7176.

Barlow, M., Cullen, H. and Lyon, B. (2002). Drought in central and southwest Asia: La Niña, the warm pool, and Indian Ocean precipitation. Journal of Climate, 15, 697700. 
Barlow, M.A. and Tippett, M.K. (2008). Variability and predictability of Central Asia river flows: Antecedent winter precipitation and large-scale teleconnections. Journal of Hydrometeorology, 9, 1334-1349.

Barnston, A.G., Chelliah, M. and Goldenberg, S.B. (1997). Documentation of a highly ENSO-related SST region in the equatorial Pacific. Atmosphere-Ocean, 35, 367-383.

Cannon, F., Carvalho, L.M., Jones, C. and Bookhagen, B. (2015). Multi-annual variations in winter westerly disturbance activity affecting the Himalaya. Climate Dynamics, 44, 441-455.

Cayan, D.R., Redmond, K.T. and Riddle, L.T. (1999). ENSO and Hydrologic Extremes in the Western United States. Journal of Climate, 12, 2881-2893.

Chiew, F.H.S. and McMahon, T.A. (2002). Global ENSO-streamflow teleconnection, streamflow forecasting and interannual variability. Hydrological Sciences Journal, 47, 505-522.

Chiew, F.H.S., Piechota, T.C., Dracup, J.A. and McMahon, T.A. (1998). El Nino/Southern Oscillation and Australian rainfall, streamflow and drought: Links and potential for forecasting. Journal of Hydrology, 204, 138-149.

Clausen, T.J., Fuggle, R., Giovannetti, F., Helland-Hansen, E. and Todini, E. (2014). Rogun Hydropower Project: Final Report of the Environmental and Social Panel of Experts. Accessed 04/04/2017.

Cullen, H.M. and Demenocal, P.B. (2000). North Atlantic influence on TigrisEuphrates streamflow. International Journal of Climatology, 20, 853-863.

Cullen, H.M., Kaplan, A., Arkin, P.A. and Demenocal, P.B. (2002). Impact of the North Atlantic Oscillation on Middle Eastern climate and streamflow. Climatic Change, 55, 315-338.

Dai, A. and wigley, T.M.L. (2000). Global patterns of ENSO-induced precipitation, Geophysical Research Letters, 27, 9, 1283-1286.

Dimri, A.P. (2013). Relationship between ENSO phases with Northwest India winter precipitation. International Journal of Climatology, 33, 1917-1923. 
Dixon, S.G. and Wilby, R.L. (2016). Forecasting reservoir inflows using remotely sensed precipitation estimates: a pilot study for the River Naryn, Kyrgyzstan. Hydrological Sciences Journal, 61, 107-122.

Emerton, R., Cloke, H. L., Stephens, E. M., Zsoter, E., Woolnough, S. J. and Pappenberger, F. (2017). Complex picture for likelihood of ENSO-driven flood hazard. Nature Communications, 8, 14796.

European Commission. (2008). Joint Progress Report by the Council and the European Commission to the European Council on the Implementation of the EU Central Asia Strategy. Accessed 04/04/2017.

Fleming, S.W. and Dahlke, H.E. (2014). Parabolic northern-hemisphere river flow teleconnections to El Niño-Southern Oscillation and the Arctic Oscillation.

Environmental Research Letters, 9, doi:10.1088/1748-9326/9/10/104007.

Gerlitz, L., Vorogushyn, S., Apel, H., Gafurov, A., Unger-Shayesteh, K. and Merz, B. (2016). A statistically based seasonal precipitation forecast model with automatic predictor selection and its application to central and south Asia. Hydrology and Earth System Sciences, 20, 4605-4623.

Hamlet, A.F. and Lettenmaier, D.P. (1999). Columbia River streamflow forecasting based on ENSO and PDO climate signals. Journal of Water Resources Planning and Management, 125, 333-341.

Hamlet, A.F., Huppert, D.D. and Lettenmaier, D.P. (2002). Economic value of longlead stream-flow forecasts for Columbia River hydropower. Journal of Water Resources Planning and Management, 128, 91-101.

Hoerling, M. and Kumar, A. (2003). The perfect ocean for drought. Science, 299, $691-694$.

Hurrell, J.W. and NCAR Staff (Eds). (2016). The Climate Data Guide: Hurrell North Atlantic Oscillation (NAO) Index (station-based). Accessed 14/12/2016.

Hurrell, J.W. and van Loon, H. (1997). Decadal variations in climate associated with the North Atlantic Oscillation. Climatic Change, 36, 301-326. 
International Research Institute (2013). Descriptions of the IRI Climate Forecast Verification Scores. 15.

Kennedy, A.M., Garen, D.C. and Koch, R.W. (2009). The association between climate teleconnection indices and Upper Klamath seasonal streamflow: Trans-Nino Index. Hydrological Processes, 23, 973-984.

Krishnaswamy, J., Vaidyanathan, S., Rajagopalan, B., Bonell, M., Sankaran, M.S., Bhalla, R.S. and Badiger, S.M. (2015). Non-stationary and non-linear influence of ENSO and Indian Ocean Dipole on the variability of Indian monsoon rainfall and extreme rain events. Climate Dynamics, 45, 175-184.

Kumar, K.K., Rajagopalan, B. and Cane, M.A. (1999). On the Weakening Relationship Between the Indian Monsoon and ENSO. Science, 284, 2156-2159.

Lee, D., Ward, P.J. and Block, P. (2008). Identification of symmetric and asymmetric responses in seasonal streamflow globally to ENSO phase. Environmental Research Letters, 13, 044031.

Mariotti, A. (2007). How ENSO impacts precipitation in southwest central Asia. Geophysical Research Letters, 34, doi:10.1029/2007GL030078.

Mason, S. J. \& Goddard, L. (2001). Probabilistic precipitation anomalies associated with ENSO. Bulletin of the American Meteorological Society, 82, 619-638.

Maurer, E.P. and Lettenmaier, D.P. (2003). Predictability of seasonal runoff in the Mississippi River basin. Journal of Geophysical Research, 108, D16.

McGregor, G. (2017). Hydroclimatology, modes of climatic variability and stream flow, lake and groundwater level variability: A progress report. Progress in Physical Geography, 41, 496-512.

Ng, J.Y., Turner, S.W.G., Galelli, S. (2017). Influence of El Niño Southern Oscillation on global hydropower production. Environmental Research Letters, 12 , 034010.

Rakhmatullaev, S., Huneau, F., Le Coustumer, P., Motelica-Heino, M. and Bakiev, M. (2010). Facts and perspectives of water reservoirs in Central Asia: A special focus on Uzbekistan. Water, 2, 307-320. 
Raskin, P., Hansen, E., Zhu, Z. and Stavisky, D. (1992). Simulation of water supply and demand in the Aral Sea Region. Water International, 17, 55-67.

Redmond, K.T. and Koch, R.W. (1991). Surface climate and streamflow variability in the Western United States and their relationship to large-scale circulation indices. Water Resources Research, 27, 2381-2399.

Reuters. (2012). Uzbek leader sounds warning over Central Asia water disputes. Available: http://www.reuters.com/article/centralasia-wateridUSL6E8K793I20120907. Last accessed 29/03/2017.

Schiemann, R., M. G. Glazirina, and Schär, C. (2007). On the relationship between the Indian summer monsoon and river flow in the Aral Sea basin. Geophysical Research Letters, 34, L05706.

Schiemann, R., Lüthi, D., Vidale, P.L. and Schär, C. (2008). The precipitation climate of Central Asia - intercomparison of observational and numerical data sources in a remote semiarid region. International Journal of Climatology, 28, 295-314.

Sene, K. (2016). Water Resources. In: Sene, K Hydro-meteorology: forecasting and applications. 2nd ed. Switzeland: Springer, pp390-394.

Singh, P. and Bengtsson, L. (2005). Impact of warmer climate on melt and evaporation for the rainfed, snowfed and glacierfed basins in the Himalayan region. Journal of Hydrology, 300, 140-154.

Syed, F., Giorgi, F., Pal, J. and King, M. (2006). Effect of remote forcings on the winter precipitation of central southwest Asia part 1: observations. Theoretical and Applied Climatology, 86, 147-160.

Syed, F.S., Giorgi, F., Pal, J.S. and Keay, K. (2010). Regional climate model simulation of winter climate over Central-Southwest Asia, with emphasis on NAO and ENSO effects. International Journal of Climatology, 30, 220-235.

Tippett, M., Goddard, L. and Barnston, A.G. (2005). Statistical-dynamical seasonal forecasts of Central-Southwest Asian winter precipitation. Journal of Climate, 18, 1831-1843. 
Wang, S., Huang, J., He, Y. and Guan, Y. (2014). Combined effects of the Pacific Decadal Oscillation and EI Nino-Southern Oscillation on global land dry-wet changes. Scientific Reports, 4, 6651.

Werner, K., Brandon, D., Clark, M. and Gangopadhyay, S. (2004). Climate index weighting schemes for NWS ESP-based seasonal volume forecasts. Journal of Hydrometeorology, 5, 1076-1090.

World Bank. (2004). Water energy nexus in Central Asia: Improving regional cooperation in the Syr Darya Basin. Washington DC.

Yadav, R.K., Yoo, J.H., Fucharski, F. and Abid, M.A. (2010). Why is ENSO influencing northwest India winter precipitation in recent decades? Journal of Climate, 23, 1979-1993. 
Table 1 Summary of river basin characteristics

Toktogul Andijan Nurek

\begin{tabular}{|l|c|c|c|}
\hline Meteorological station & Naryn & Uzgen & Garm \\
\hline Meteorological station elevation $(\mathrm{m})$ & 2039 & 1014 & 1350 \\
\hline Average annual precipitation $(\mathrm{mm})$ & 315 & 732 & 827 \\
\hline Basin area above inflow gauge $\left(\mathrm{km}^{2}\right)$ & 47,052 & 12,348 & 31,059 \\
\hline Average annual inflow $\left(\mathrm{m}^{3} \mathrm{~s}^{-1}\right)$ & 445 & 133 & 662 \\
\hline Month with most precipitation & May & April & April \\
\hline Month with most discharge & June & June & July \\
\hline \% of annual precipitation in Apr-Sep & 68 & 41 & 39 \\
\hline \% of annual flow in Apr-Sep & 77 & 77 & 83 \\
\hline Inflow as \% annual station precipitation & 36 & 47 & 83 \\
\hline
\end{tabular}

Table 2 Spearman rank correlation for months and period mean indices versus following April-September inflow anomalies $(p<0.05, p<0.01)$

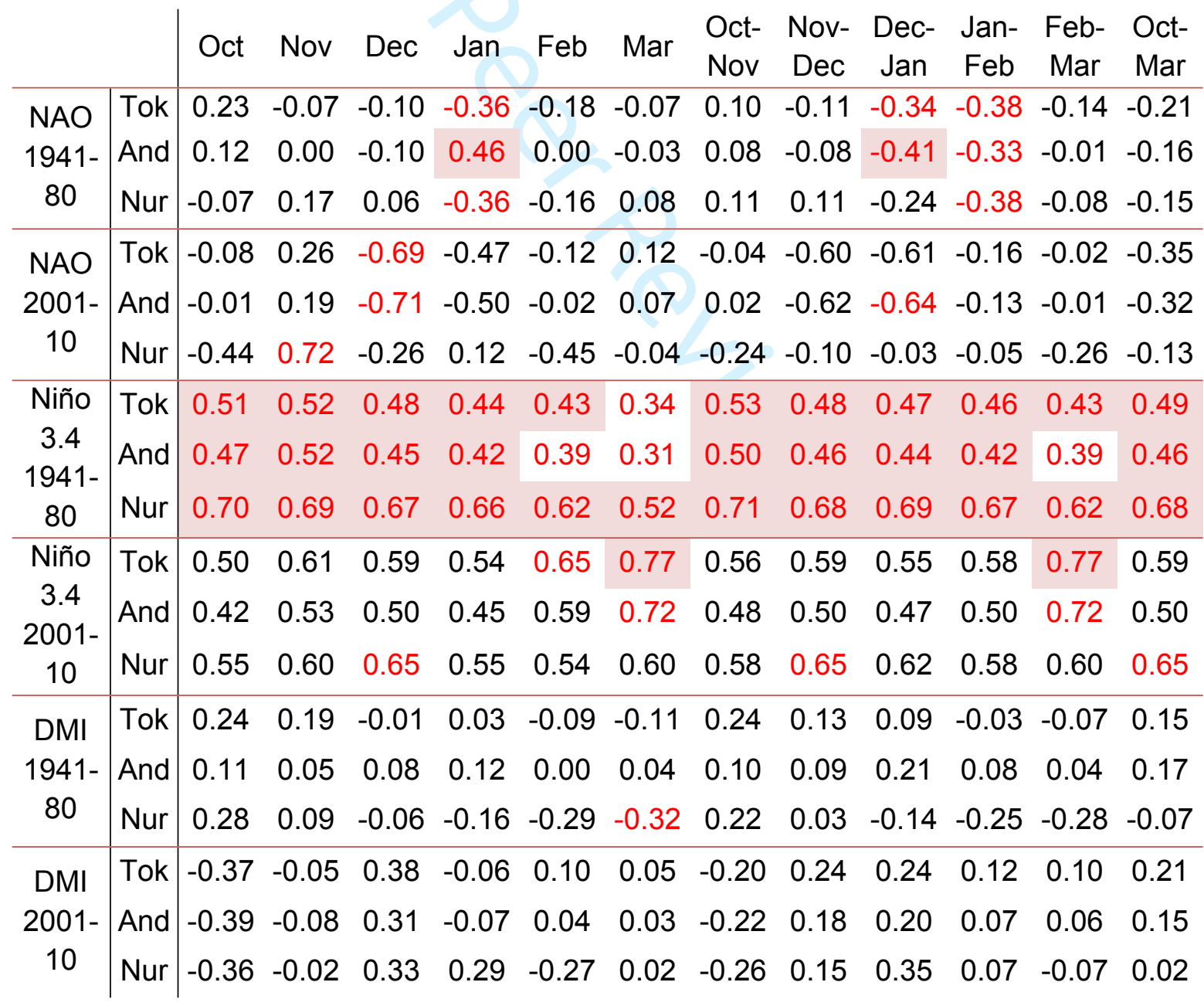


Table 3 Heidke Hit Proportion scores for mean April-September Nurek inflow anomalies conditional on November-December and October-March Niño 3.4.

\begin{tabular}{c|c|c|c} 
Calibration period & Validation period & $\begin{array}{c}\text { November- } \\
\text { December } \\
\text { Niño 3.4 }\end{array}$ & $\begin{array}{c}\text { October- } \\
\text { March Niño 3.4 }\end{array}$ \\
\hline $1941-1974$ & $1975-2016$ & 0.51 & 0.51 \\
\hline $1975-2016$ & $1941-1974$ & 0.59 & 0.53
\end{tabular}

Table 4a, $\mathbf{4 b}$ and 4c Likelihood of summer (April-September) Nurek inflow tercile (high, average, low) depending on prior November-December Niño 3.4 phase in (a) 1941-2016, (b) 1941-1974 and (c) 1975-2016 and. Niño 3.4 terciles were based on the widely accepted definition ${ }^{10}$ of $\pm 0.5^{\circ} \mathrm{C} \mathrm{SST}$ anomaly (equating to approximately $26^{\circ} \mathrm{C}$ and $27^{\circ} \mathrm{C}$ for La Niña and El Niño phases respectively). The most likely inflow category is shown in red.

\begin{tabular}{|l|l|l|l|}
\hline (a) 1941-2016 & High & Average & Low \\
\hline El Niño & 0.636 & 0.318 & 0.045 \\
Neutral & 0.231 & 0.346 & 0.423 \\
La Niña & 0.143 & 0.333 & 0.524 \\
\hline & & & \\
(b) 1941-1974 & High & Average & Low \\
\hline El Niño & 0.778 & 0.222 & 0.000 \\
Neutral & 0.267 & 0.400 & 0.333 \\
La Niña & 0.100 & 0.300 & 0.600 \\
\hline & & & \\
(c) 1975-2016 & High & Average & Low \\
\hline El Niño & 0.615 & 0.308 & 0.077 \\
Neutral & 0.182 & 0.273 & 0.545 \\
La Niña & 0.182 & 0.364 & 0.455 \\
\hline
\end{tabular}

\footnotetext{
${ }^{10}$ https://origin.cpc.ncep.noaa.gov/products/analysis monitoring/ensostuff/ONI v5.php
} 


\section{Figure legends}

Figure 1 Study catchments (a) location of reservoirs, river gauges and meteorological stations; (b) available inflow series (observed); and (c) reconstructed summer inflow series (Nurek only).

Figure 2 Monthly Niño 3.4 correlated with monthly NCEP (a) precipitation rate or (b) temperature during the years 1950-2014 at lead times 0-3 months (left column shows target month, with index month varied to account for lead time). Yellow/dark blue areas are significant at $p=0.05$, orange/pink at $p=0.01$.

Figure 3 Exceedance probabilities of April-September inflow anomalies according to previous October-March index phase (or Apr-Sep temperature) for the period 19411980 ( 0.33 and 0.66 tercile boundaries shown in header).

Figure 4 (a) Model of enhanced moisture flux to Central Asia under EI Niño conditions during September-November and March-May (adapted from Mariotti, 2007). Linear correlation coefficient between Niño 3.4 and GPCP precipitation for the period 1979-2015 during (b) September-November and (c) March-May.

Figure 5 Summer inflows to Nurek shown as (a) anomalies $\left(\mathrm{m}^{3} \mathrm{~s}^{-1}\right)$ conditioned by November-December Niño3.4 during 1941-1980 (left), 1981-2016 (centre) and 19412016 (right); and (b) mean discharge $\left(\mathrm{m}^{3} \mathrm{~s}^{-1}\right)$ in relation to November-December Niño3.4 during 1941-1992 (blue dots) and 2000-2015 (red dots).

Figure 6 A procedure for creating early seasonal outlooks for reservoir inflows in Tajikistan. 


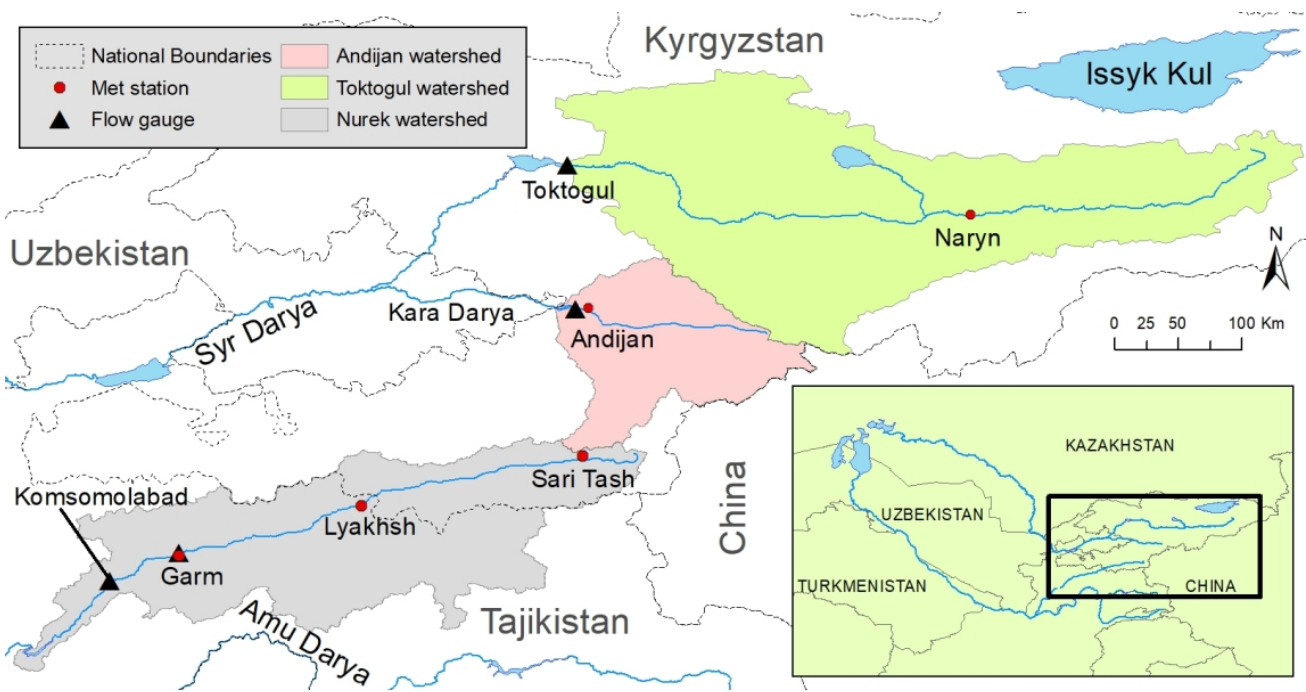

Figure 1 Study catchments (a) location of reservoirs, river gauges and meteorological stations; 


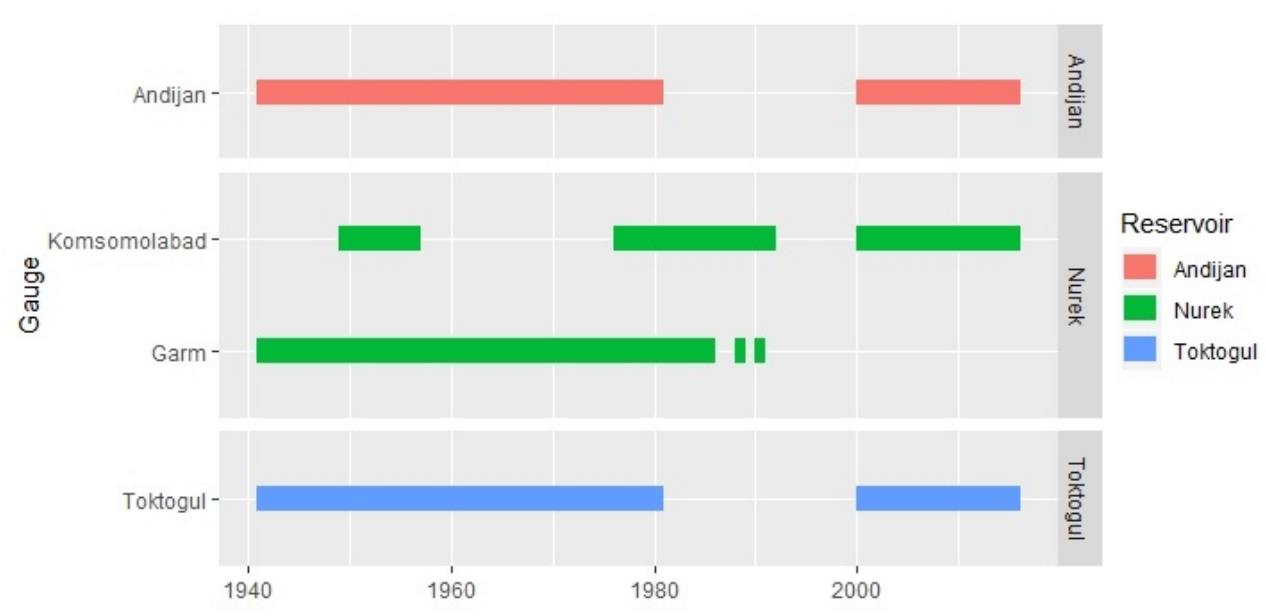

Figure 1 (b) available inflow series (observed) 


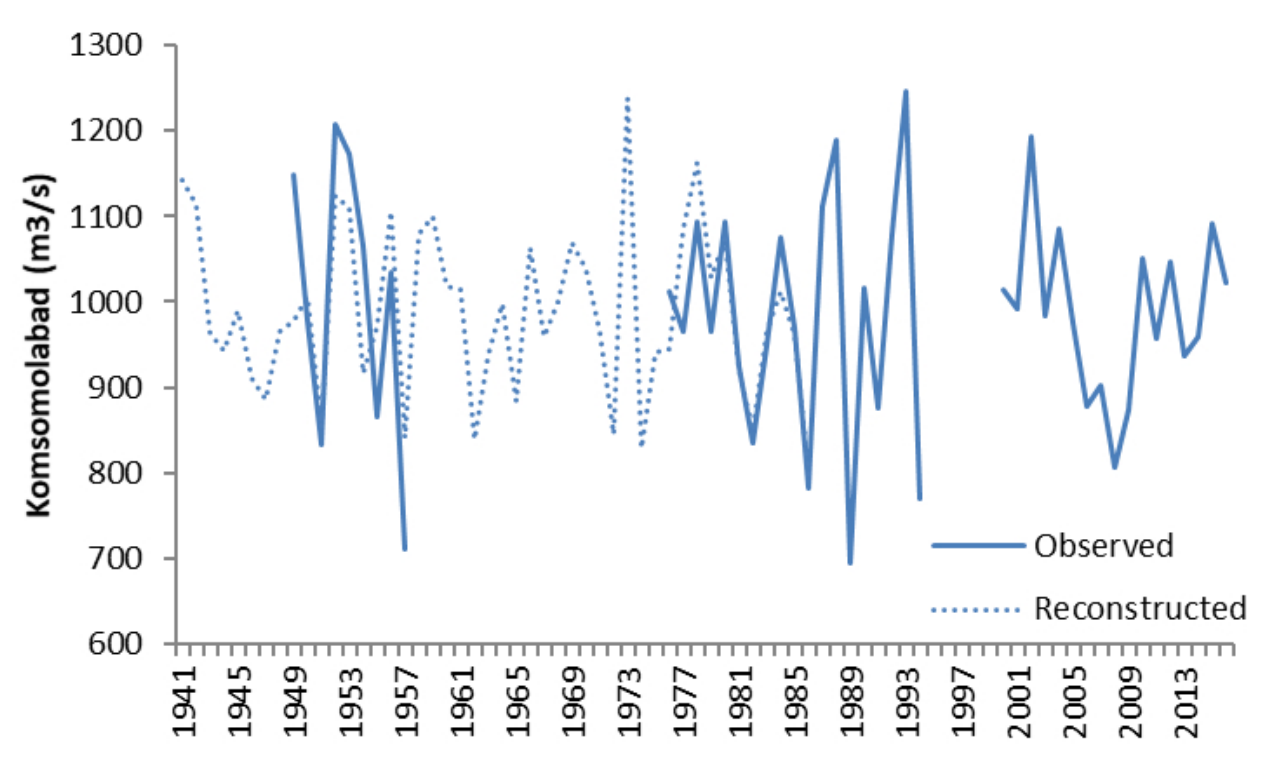

Figure 1 (c) reconstructed summer inflow series (Nurek only). 
(a)

Figure 2a Monthly Niño 3.4 correlated with monthly NCEP (a) precipitation rate during the years 1950-2014 at lead times 0-3 months (left column shows target month, with index month varied to account for lead time). Yellow/dark blue areas are significant at $p=0.05$, orange/pink at $p=0.01$. 
(b)

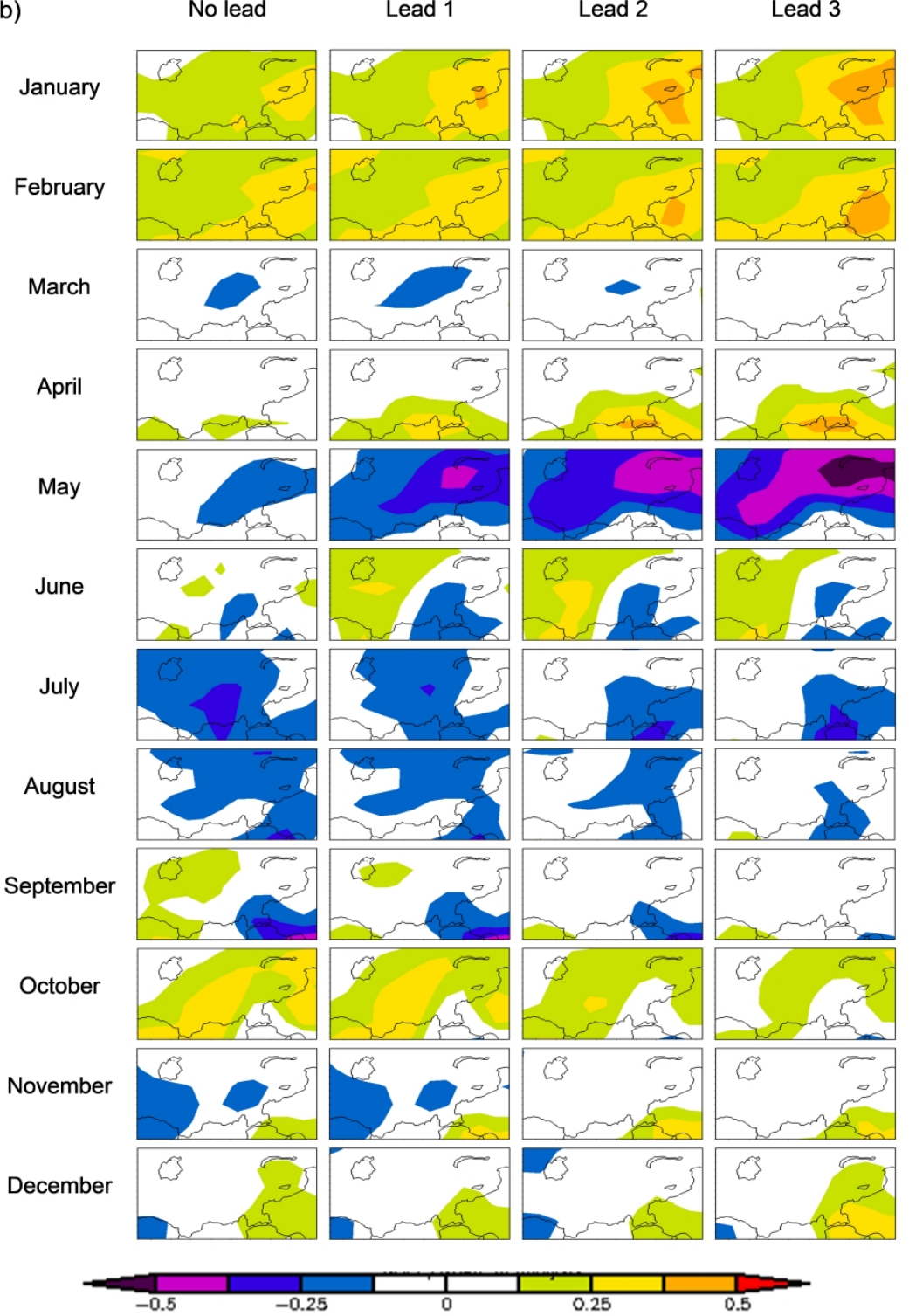

Figure 2b As in Figure 2a but for air temperature. 

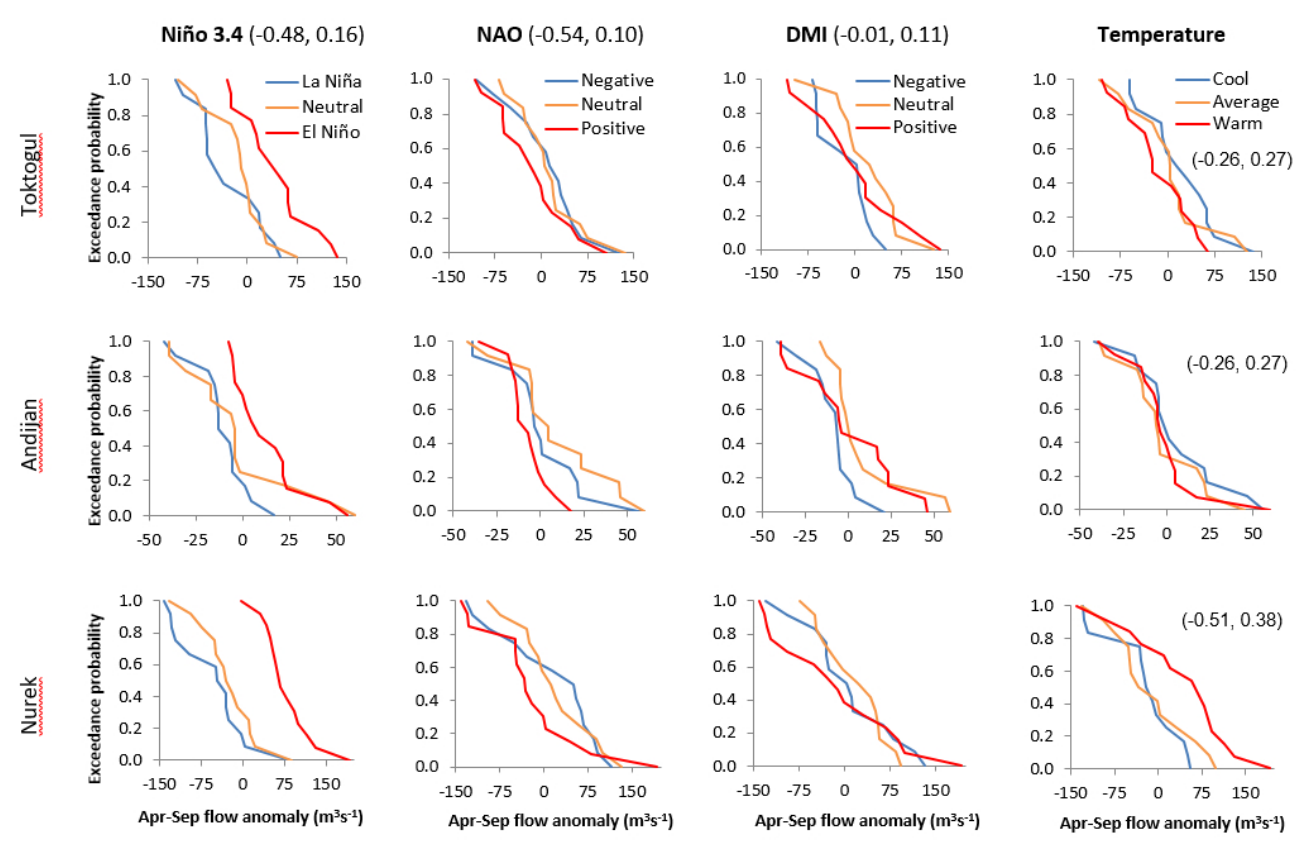

Figure 3 Exceedance probabilities of April-September inflow anomalies according to previous October-March index phase (or Apr-Sep temperature) for the period 1941-1980 (0.33 and 0.66 tercile boundaries shown in header). 
$1941-1980$

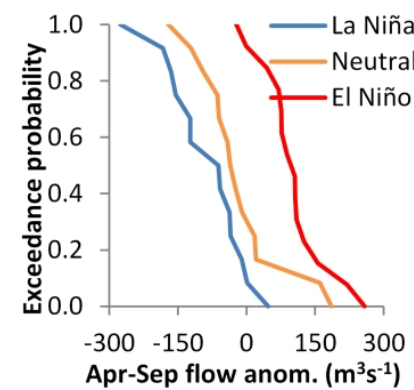

1981-2016*

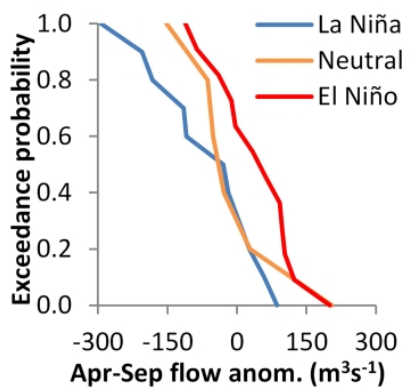

$1941-2016^{*}$

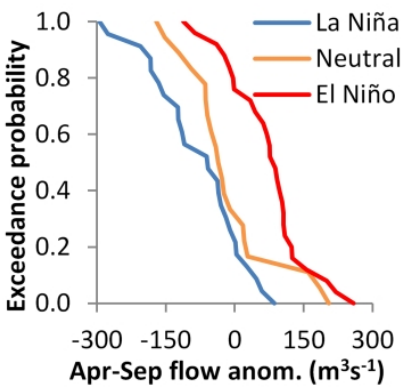

Figure 4a Summer inflows to Nurek shown as (a) anomalies (m3s-1) conditioned by November-December Niño3.4 during 1941-1980 (left), 1981-2016 (centre) and 1941-2016 (right); 


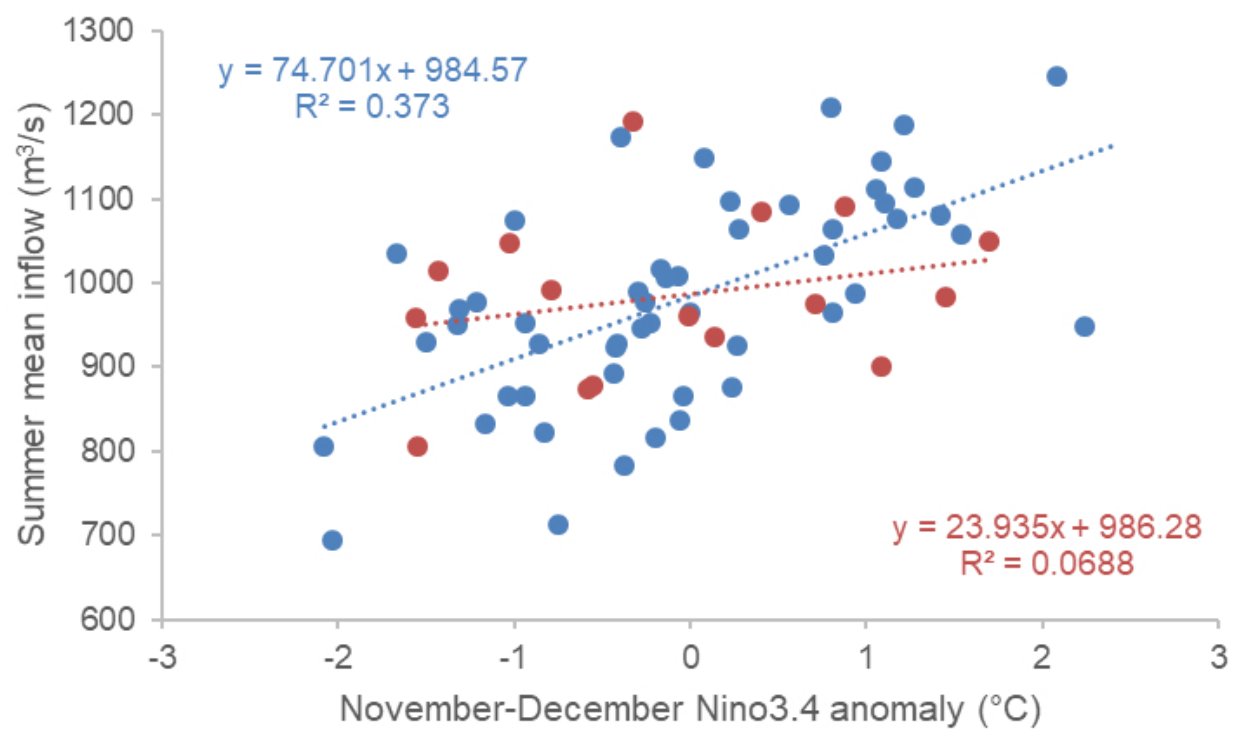

Figure 4b Summer inflows to Nurek shown as (b) mean discharge (m3s-1) in relation to NovemberDecember Niño3.4 during 1941-1992 (blue dots) and 2000-2015 (red dots). 
(a)

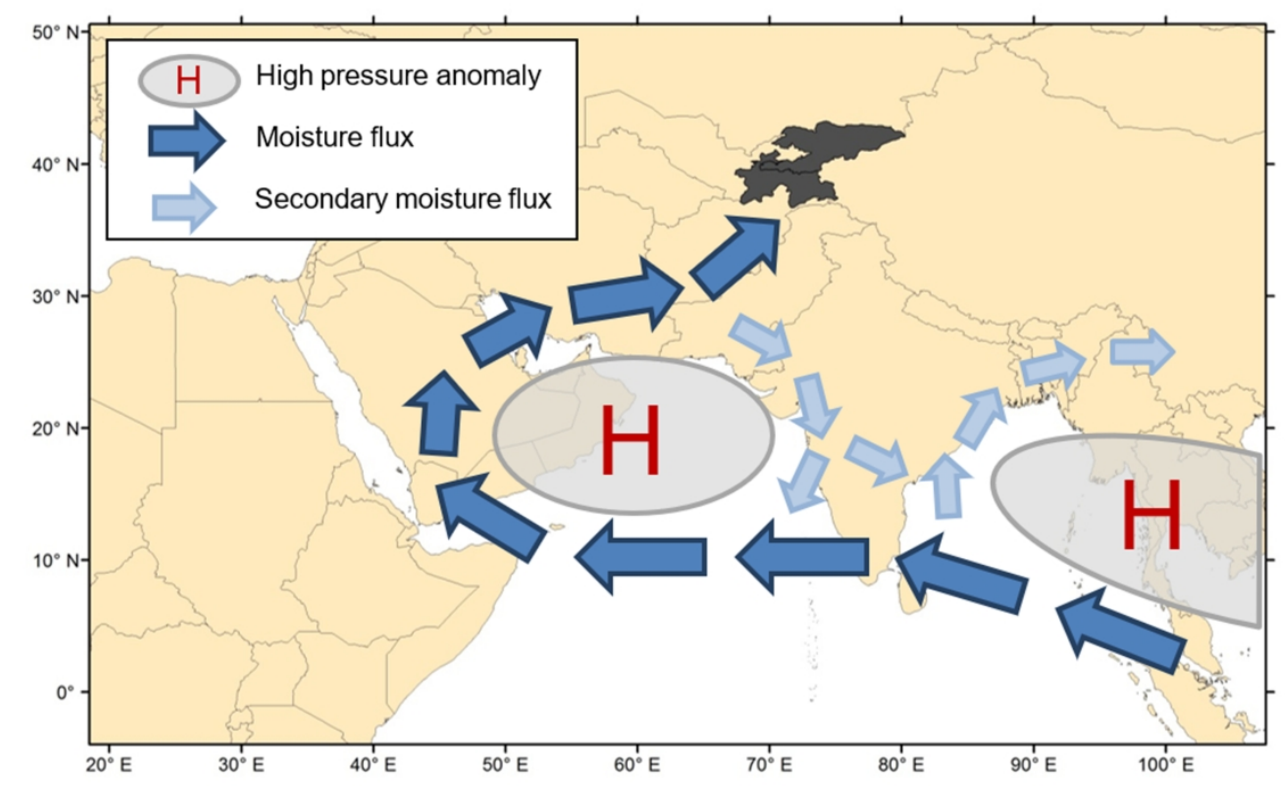

(b)

(c)
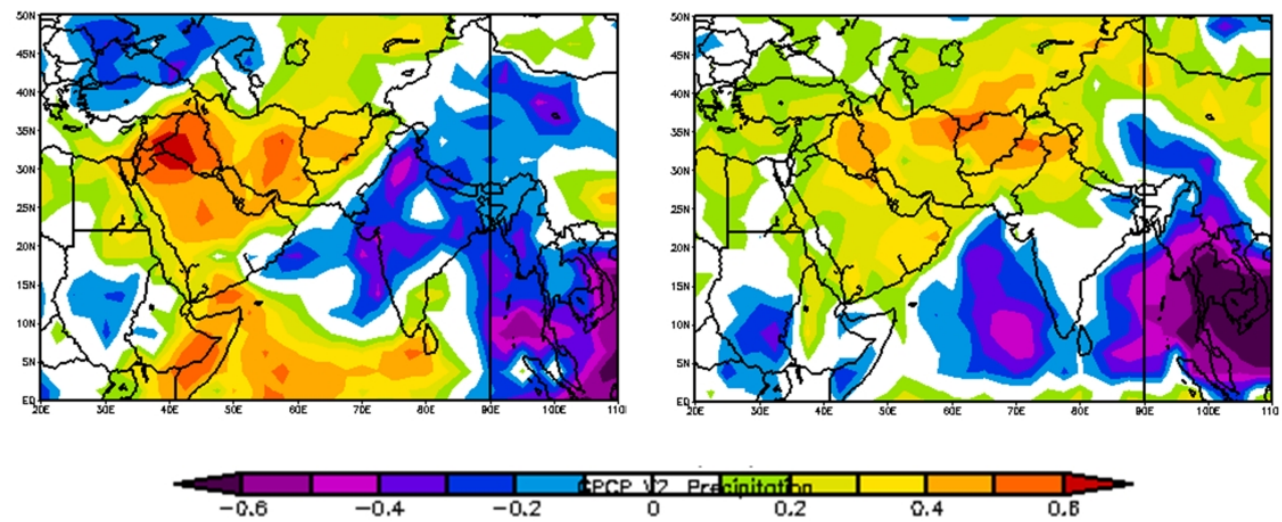

Figure 5 (a) Model of enhanced moisture flux to Central Asia under El Niño conditions during SeptemberNovember and March-May (adapted from Mariotti, 2007). Linear correlation coefficient between Niño 3.4 and GPCP precipitation for the period 1979-2015 during (b) September-November and (c) March-May. 


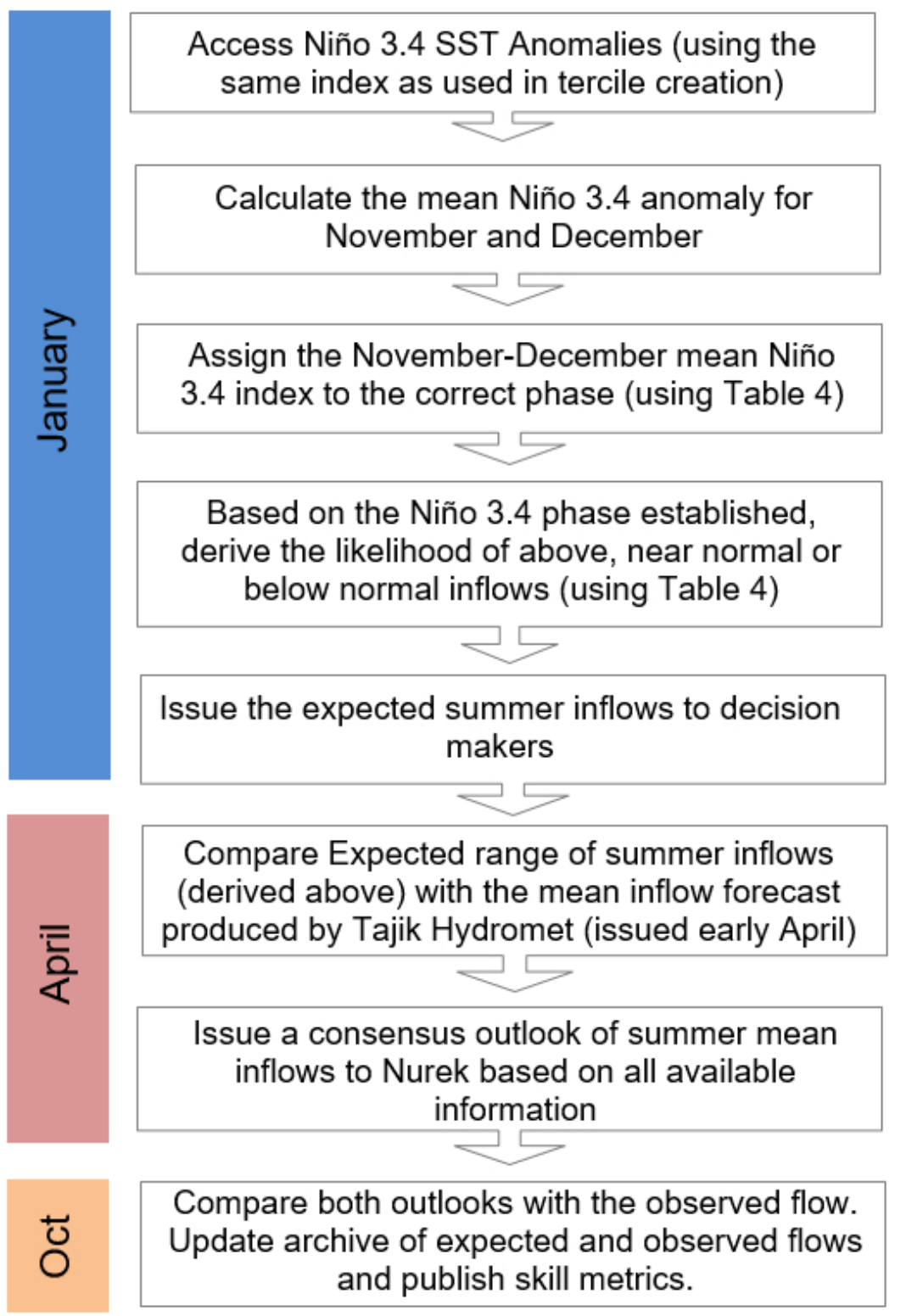

Figure 6 A procedure for creating early seasonal outlooks for reservoir inflows in Tajikistan. 